\title{
Different Perspectives on Poverty in Proverbs, Sirach, and 4QInstruction: Wisdom in Transit ${ }^{1}$
}

\author{
Pieter M. Venter (University of Pretoria)
}

\begin{abstract}
Poverty is referred to in Proverbs, as well as Sirach and 4QInstruction. These books do show some mutual tendencies, shared elements and a similar mode of literature, but are also part of a dynamic process. Reference to poverty in these books is therefore linked to the changing provenance of each of these books. The use of wisdom language to refer to this phenomenon, was in flux, dynamically moving from one era to a next, from one scenario to another. This paper proposes that the literal as well as metaphorical use of poverty in the book of Proverbs was followed by a more literal use in Ben Sirach and a more metaphorical meaning in $4 Q$ Instructions.
\end{abstract}

KEYWORDS: Proverbs; Ben Sirach; Qumran; Wisdom; Poverty.

\section{A INTRODUCTION}

The books of Proverbs, Sirach and 4QInstruction have a "family resemblance." ${ }^{2}$ These books show some mutual tendencies, shared elements and a similar "mode of literature." 3 But they are also part of a dynamic process. The

* Article submitted: 14/03/2017; peer-reviewed: 26/04/2017; accepted: 3/05/2017. Pieter M. Venter, "Different Perspectives on Poverty in Proverbs, Sirach, and 4QInstruction: Wisdom in Transit," Old Testament Essays 30 (2017): 478-502, doi: http://dx.doi.org/10.17159/2312-3621/2017/v30n2a17

1 This article is dedicated to colleague Izak Spangenberg. He already published an essay on poverty in wisdom literature in 1991. See Izak J. J. (Sakkie) Spangenberg, " "The Poor will Always Be with You': Wealth and Poverty in a Wisdom Perspective," in Plutocrats and Paupers: Wealth and Poverty in the Old Testament, ed. Hendrik L. Bosman, Ignatius G. P. Gous, and Izak J. J. Spangenberg (Pretoria: J. L. van Schaik, 1991), 228-246. We more than once found each other in the same area of the study of wisdom and apocalyptics.

2 Cf. Mark R. Sneed, “'Grasping after the Wind': The Elusive Attempt to Define and Delimit Wisdom," in Was There a Wisdom Tradition? New Prospects in Israelite Wisdom Studies, ed. Mark R. Sneed (Atlanta: SBL Press, 2015), 59.

3 Sneed, "Elusive Attempt," 41. At present, the category of "wisdom literature" is hotly debated. Cf. the title of the publication by Mark R. Sneed, ed., Was there a Wisdom Tradition? New Prospects in Israelite Wisdom Studies (Atlanta: SBL Press, 2015). Mark R. Sneed, "Introduction," in Was there a Wisdom Tradition? New Prospects in Israelite Wisdom Studies, ed. Mark R. Sneed (Atlanta: SBL Press, 2015), 
activity of people expressing themselves mainly in terms of what can be called wisdom language, was in flux, dynamically moving from one era to a next, from one scenario to another. Adams ${ }^{4}$ rightly titled his publication "Wisdom in Transition."

This article studies the idea of poverty as it appears in the books of Proverbs, Sirach and 4QInstruction ${ }^{5}$ within the context of the evolving trends in sapiential literature during the time of the Second Temple $(516$ BCE-70 CE). Wright calls the theme of "riches and poverty," one of the most important

3 indicates that a wide spectrum of positions is found on Wisdom. Some see it as a tradition, others hold the older paradigm position that wisdom literature is a foreign body (a Fremdkörper) to the rest of the Bible, and others take a mid-position between these two views. Will Kynes, "The Modern Scholarly Wisdom Tradition and the Threat of Pan-Sapientialism: A Case Report," in Was there a Wisdom Tradition? New Prospects in Israelite Wisdom Studies, ed. Mark R. Sneed (Atlanta: SBL Press, 2015), 11-38, agrees with Sneed that wisdom is one of several complementary modes in the HB. These texts can no longer be read only in terms of a genre. This is restrictive. There are "intertextual connections" (Kyne, "Modern Scholarly," 32) between these texts and the rest of the HB and they cannot be ascribed "to a particular ancient tradition or movement complete with its own social setting and group of authors and tradents" (Kyne, "Modern Scholarly," 32). On the other hand, it cannot be denied that these texts "share some basic premises in their understanding of the world that are different from the premises reflected in other books of the Old Testament." See Annette Schellenberg, "Don't Throw the Baby Out with the Bathwater: On the Distinctiveness of the Sapiential Understanding of the World," in Was there a Wisdom Tradition? New Prospects in Israelite Wisdom Studies, ed. Mark R. Sneed (Atlanta: SBL Press, 2015), 116. When compared to the Torah, the prophetical literature, the apocalyptic and the historical literature, the wisdom literature shows a unique purpose, and an individual mode (cf. Sneed, "Elusive Attempt," 47-48). These books are to be read in terms of a mutual affinity with a unique focus, not imitating "generic conventions" (Sneed, "Elusive Attempt," 62), but rather generating new conventions within an intertextual and dynamic context.

4 Samuel L. Adams, Wisdom in Transition: Act and Consequence in Second Temple Instructions, JSJSup (Leiden, Brill, 2008). In his study he not only discussed the progress made in present Sapiential studies since Klaus Koch's 1951 theory of a TunErgehen-Zusammenhang (deed-result-coherence) (Klaus Koch, "Gibt es ein Vergeltungsdogma im Alten Testament?" ZTK 52 [1951]: 1-42) in proverbial wisdom literature, but also discusses the transitional character of wisdom literature during the Second Temple period. He pays attention to the development during the last centuries BCE which was influenced by some changes, i.a. the rise in some sections of Judaism in the belief of after-life. In 4QInstruction, e.g., death and the prospect of living in a world beyond death is a very prominent theme.

5 4QInstruction is a theoretical reconstruction from scrolls 4Q415-418, 4Q 423 and 1Q26. It was formerly called "Sapiential A." In recent years it is known as "4QInstruction." 
issues in these books, even more than that, one of the "most pervasive topics in Jewish wisdom."6

\section{B POVERTY IN THE BOOK OF PROVERBS}

The oldest material for the purpose of our study is found in the book of Proverbs. It is difficult to exactly date the book of Proverbs. This compendium of "previously existing collections" " was probably finalised during the postexilic period. In all likelihood, it was compiled "in the Persian period (539-333 BCE).," It is definitely older than Ben Sirach and 4QInstruction, and was in all probability one of the sources both these works utilised.

\section{The Provenance of Proverbs}

Those who see the book of Proverbs as representing a wisdom tradition, link its provenance to scribes and sages. Pleins ${ }^{9}$ studied the use in Proverbs of the אבל (poor), דש (poor), מחסוֹ (impoverished) and the lesser used אביון (pords (needy) and עני (wretched). According to Perdue ${ }^{10}$ the study of these terms leads directly to the social character of the book of Proverbs. It is not possible to "give an undistorted description even of the social idealization of folk wisdom, let alone of the social realities underlying it."11 There is, however, consensus among scholars that these proverbs reflect "an aristocratic worldview and ethos." 12 These words show the beliefs and mental attitude of an educated class of people. These people lived in the cities. The proverbs they used reflect the ideas of those who "were in political and social upper echelons of power and wealth."13

6 Benjamin G. Wright, III, "The Categories of Rich and Poor in the Qumran Sapiential Literature," in Sapiential Perspectives: Wisdom Literature in the Light of the Dead Sea Scrolls: Proceedings of the Sixth International Symposium of the Orion Center, 20-22 May 2001, ed. John J. Collins, Gregory E. Sterling and Ruth Clements (Leiden: Brill 2004), 101.

7 Richard J. Clifford, "Proverbs, Book of," NIDB 4: 656.

8 Clifford, "Proverbs," 656.

9 J. David Pleins, "Poverty in the Social World of the Wise," JSOT 37 (1987): 67.

10 Cf. Leo G. Perdue, The Sword and the Stylus: An Introduction to Wisdom in the Age of Empires (Grand Rapids, MI: William B. Eerdmans, 2008), 100.

11 Michael V. Fox, "The Social Location of the Book of Proverbs," in Texts, Temples, and Traditions: A Tribute to Menahem Haran, ed. Michael V. Fox (Winona Lake IN: Eisenbrauns, 1996), 239.

12 Perdue, The Sword and the Stylus, 100.

13 Perdue, The Sword and the Stylus,"103. 


\section{Ambivalence Regarding the Poor}

The terminology used in what can be called (mainly) sapiential literature "reveals a startling contrast"14 with that used in the prophetic literature and the Psalms. In contrast to the prophetic literature the different proverbs display an "ambivalence" 15 in attitude toward the poor. The sages had a "divergent understanding of poverty." 16 Poverty was seen as part and parcel of the social structure, but poverty also brought about dire consequences (Prov 14:20; 18:23; 22:7). Poverty was also seen as the result of laziness (Prov 6:6-11; 10:4-5; 24:30-34; 26:13-16) and of wickedness (Prov 12:3; 13:25, 33). Righteous people were also found among the poor (Prov 15:16-17; 16: 16 and 19; 17:1; 28:6). The wise will not oppress the poor, as that would be an insult to the One who created him (Prov 14:31). Due to competing viewpoints among different groups and to ever-changing social circumstances the viewpoint on poverty was changed and reformulated from time to time. Pleins would rather see the terms for poverty as having "heuristic value" 17 than referring to literal poverty. These words were used to teach the student "the proper attitude toward wealth and wisdom." $" 18$

Not only does the term "poor" have various levels of meaning, but several other themes are also found in the wisdom rhetoric of Proverbs. Perdue points out themes like "wisdom leads to theological understanding and ethical conduct" 19 and "wisdom as goddess and instrument of creation." 20 Themes like "creation and justice," 21 "creation and theodicy,"22 "creation and economic justice,"23 "creation and the poor," 24 "organs of perception and knowledge," 25 and "Yahweh as Creator of rich and poor," ${ }^{26}$ are also found in Proverbs.

14 Pleins, "Poverty in the Social World," 63.

15 Pleins, "Poverty in the Social World," 72.

16 Pleins, "Poverty in the Social World," 72.

17 Pleins, "Poverty in the Social World," 72.

18 Pleins, "Poverty in the Social World," 72.

19 Leo G. Perdue, Wisdom Literature: A Theological History (Louisville:

Westminster Kohn Knox Press, 2007), 49.

20 Perdue, Wisdom Literature, 49.

21 Perdue, Wisdom Literature, 59.

22 Perdue, Wisdom Literature, 63.

23 Perdue, Wisdom Literature, 64.

24 Perdue, Wisdom Literature, 64.

25 Perdue, Wisdom Literature, 65.

26 Perdue, Wisdom Literature, 66. 


\section{Poverty as Metaphor}

Perdue's thesis is that creation expressed through cultural metaphors is the "central theological theme of the sages." 27 The sages used metaphors they took over from mythic traditions of the ANE. They structured an imaginary world with a variety of metaphors to portray the cosmos as the creation of God in which he instilled a specific order. Perdue ${ }^{28}$ arranges these metaphors of the sages into four categories: "divine creation and providence," "creation and anthropology," "creation and goddess Wisdom," and "sapiential creation and the discourse of power." Within this context Perdue states that the poor's right is based "on a sapiential understanding of creation and providence." 29 As creator of the world, God was the supports humanity. He blesses the righteous, protects and provides for the poor, and castigates the wicked. Both rich and poor were created by God. Justice requires one to pay respect and support all categories of people. While ancient Israel's social system, as formulated in the Law, was generally based on family relationship and charity to give alms to the poor, the support of the poor in Proverbs is rather based on the way the sages saw and interpreted the world as God's creation.

\section{$4 \quad$ Sandoval and Loader}

The issue of Proverbs' use of metaphors play a central role in the debate between Sandoval (2006) and Loader (2006). Timothy Sandoval ${ }^{30}$ proposes that a "critical mass of proverbs ... reveals a certain moral vision and certain patterns of figurative use of wealth and poverty language in Proverbs." $\mathrm{He}$ proposes therefore a figurative reading of Proverbs. Alfred Loader opposes this "overtly figurative reading" 31 and indicates that "literal readings are not only possible, but also necessary" 32 when reading Proverbs.

Several moral discourses are found in the HB. According to Sandoval ${ }^{33}$ the discourse of wealth and poverty is not only found in the book of Proverbs next to other themes, but is in fact the main theme of that book. The book comprises of "three distinct sub-discourses." ${ }^{34}$ These overlapping discourses are "wisdom's virtues discourse," 35 "a discourse of social justice,"

\footnotetext{
27 Perdue, Wisdom Literature, 37.

28 Perdue, Wisdom Literature, 73-76.

29 Perdue, Wisdom Literature, 61.

30 Timothy Sandoval, The Discourse of Wealth and Poverty in the Book of Proverbs (Leiden-Boston: Brill, 2006), 208.

31 James Alfred Loader, "Metaphorical and Literal Readings of Aphorisms in the Book of Proverbs," HTS 62 (2006): 1179.

32 Loader, "Metaphorical," 1179.

33 Sandoval, Discourse, 4.

34 Sandoval, Discourse, 205.

35 Sandoval, Discourse, 69.
} 
discourse of social observation." ${ }^{37}$ Sandoval follows Ricoeur's ${ }^{38}$ known advocacy that a text is able to construct a symbolic world for the reader. The discourses in Proverbs are metaphorical, creating a world of ideas for the readers. The main discourse of wealth and poverty in Proverbs on both textual as well as extra-textual level presents a "matrix of symbolic associations and patterns of value." 39 This matrix applies to not only wealth and poverty, but also to matters like social status, value, and identity.

The discourse of wealth and poverty is generally held to be ambiguous or inconsistent. ${ }^{40}$ Scholars usually ascribe this amphibology either to the complex reality they observed, or to a variety of social provenances for the collected sayings in the book. Sandoval does not agree with his view of ambiguity. According to Sandoval these texts are nearly always read in literal terms. Sandoval finds an "appeal to historical development or multiple social contexts" ${ }^{\prime 1}$ unsatisfactory to explain these different levels. He rather prefers to read the book's moral discourse according to its "metaphorical nature." ${ }^{2}$ The "figurative interpretative possibilities" ${ }^{43}$ of the text invites the reader to explore its "figurative qualities." ${ }^{4}$ It should not be understood "in overly literal fashion." 45

According to Sandoval, Proverbs constructs "a symbolic view of the world" 46 which represents "the true nature of the cosmos." 47 This structure promotes beliefs and moralities that see wealth as a virtue to be sought and poverty as something to be avoided. In the sub-discourse of social justice, however, a personal vocabulary for the poor is implemented. Rather than depicting wealth and poor in terms of a virtue discourse, these terms are indicating a "particular economic ethic" 48 as part of a social discourse. The learner is sensitised to the position of those who are poor and learned to be kind to "economically marginalized persons." ${ }^{\text {"9 }}$ The third discourse (next to that on

36 Sandoval, Discourse, 69.

37 Sandoval, Discourse, 69.

38 This way of understanding the literature in Proverbs comes near to the approach followed in speech act theory. While Loader investigates the text and its background, Sandoval pays attention to the reader in front of the text as well.

39 Sandoval, Discourse, 25.

40 Cf. Sandoval, Discourse, 31.

41 Sandoval, Discourse, 36.

42 Sandoval, Discourse, 39.

43 Sandoval, Discourse, 205.

44 Sandoval, Discourse, 205.

45 Sandoval, Discourse, 205.

46 Sandoval, Discourse, 206.

47 Sandoval, Discourse, 206.

48 Sandoval, Discourse, 207.

49 Sandoval, Discourse, 207. 
virtue and sociality), the discourse of "social observation," 50 indicates the effect of wealth and poverty in society. These three sub-discourses overlap each other and prevents one from understanding wealth and poverty only in terms of an act-consequence construction. It is therefore Sandoval's thesis that the sayings in Proverbs disclose "a certain moral vision and certain patterns of figurative use of wealth and poverty language." 51

Loader is not convinced that a single hermeneutical perspective, whether it is metaphorical or symbolical, can be found in the book of Proverbs. The topics referred to in the book are too variegated to reduce the coherence of the book to one unitary moral vision. The coherence rather exists in the use of several sapiential ${ }^{52}$ perspectives and central ${ }^{53}$ motifs. Cohesiveness is also advanced by an "impressive literary employment of figures," 54 including metaphors and an array of poetic techniques.

Loader does not agree with Sandoval's view that the figurative language used in the prologue in Prov 1:1-7 provides a "hermeneutical cue for a metaphorical understanding" 55 of the rest of Proverbs. A metaphorical reading is indeed invited by some of the language used in the book, but a metaphorical reading "cannot be generalised to such an extent that metaphorical readings are privileged." 56 According to Loader, to understand Prov 1:7 as an indicator to read all of the book of Proverbs "with a sensitivity to figurative aphorisms and motifs is greatly exaggerated." 57

Loader sees the book of Proverbs as an anthology of materials collected for teaching life skills to others. The book sharpens the didactic skills of established sages. The book enables them to use "even the most enigmatic sapiential literary genres" 58 when teaching others about wisdom. Although many of the genres used by them make a metaphorical understanding possible, there are many cases where such an understanding is unnecessary, and sometimes even impossible. An aphorism can even contain a literary metaphor, but that does not mean that it is to be understood metaphorically. ${ }^{59}$

50 Sandoval, Discourse, 207.

51 Sandoval, Discourse, 208.

52 Loader, "Metaphorical," 1197, indicates perspectives "such as the creational order, the deed-consequence nexus and the religious mooring of wisdom."

53 Loader, "Metaphorical," 1197, mentions motives like "concept of wisdom, discipline and human possibilities."

54 Loader, "Metaphorical," 1197.

55 Loader, "Metaphorical," 1188.

56 Loader, "Metaphorical," 1188.

57 Loader, "Metaphorical," 1187.

58 Loader, "Metaphorical," 1186.

59 Cf. Loader, "Metaphorical," 1196. 
It can be agreed with Loader that it is not tenable to privilege a metaphorical reading. Even when reading Proverbs metaphorically, too many metaphors are used to single out the metaphors for poverty as the centre of Proverbs. On the other hand, relating the metaphors and references to a social world of which so little is really known, makes the speech act when reading of Proverbs less effective. Sandoval is correct to pay attention to the metaphorical aspect as well. Perdue indicated clearly the sages' "substantial use of metaphors in their teaching about the two related creation traditions: ... cosmology and anthropology." 60

\section{Summary Proverbs}

Proverbs is a variegated collection of newer and older wisdom sayings. It was finalised in the post-exilic time, probable during the Persian period. It's provenance was the educated elite. The sayings display an ambivalent attitude towards the poor. Some, like Pleins, ${ }^{61}$ understand the reference to poverty as a heuristic tool rather than a literal indication of deprivation. Perdue ${ }^{62}$ links poverty to the cultural metaphors used for creation in Proverbs. Sandoval sees the metaphor of wealth and poverty as the main theme in Proverbs. Loader does not agree with a metaphorical reading of Proverbs, at least not as the privileged strategy. There are several sapiential perspectives in Proverbs and poverty and they are used in a constellation of terms. The term poverty is to be understood in literal sense as well, if not most of the time. Sneed ${ }^{63}$ and Kynes ${ }^{64}$ advise that the wisdom in Proverbs be understood in terms of a complimentary mode. Poverty is not only to be read within a larger context of ideas in Proverbs, but also in terms of an intertextual context.

This ambivalence opened up at least two types of interpretation in the later reading of Proverbs. Study of the utilising of Proverbs in later years in Sirach and 4QInstruction indicates two different directions. As will be shown, Ben Sira mainly followed the literal meaning of wisdom and poverty. 4QInstruction, on the other hand, followed ta metaphorical use of the book, developing it into a theology of the poor. Under totally different circumstances and under the influence of other literature (inter alia apocalyptic literature) different visions were held on poverty.

60 Perdue, Wisdom Literature, 73.

61 Pleins, "Poverty in the Social World."

62 Perdue, Wisdom Literature.

63 Sneed, "Introduction."

64 Kynes, "Modern Scholarly." 
486 Venter, "Different Perspectives on Poverty," OTE 30/2 (2017): 478-502

\section{SIRACH}

\section{Provenance of Sirach}

This work ${ }^{65}$ was originally written in Hebrew between 195 and 175 BCE. ${ }^{66}$ Sira's grandson started translating it into Greek after $132 \mathrm{BCE},{ }^{67}$ and finalised the work around 117 BCE. ${ }^{68}$ The book reflects the social world of the third century BCE Judea, a "period dominated by Hellenism." ${ }^{\text {" T9 }}$ The book is "a codified reflection of the social and religious situation in Palestine" $" 70$ of that time. Ben Sira and his students belonged to the retainer class. ${ }^{71} \mathrm{He}$ regarded himself as a scribe or a sage, and a wisdom teacher. His life stood in contrast to that of manual labourers. However, his efforts were "essential for the well-being of the community." "72 As scribal sage he was a member of the "retainers with scribal, legal, cultural and religious functions, some of which may have overlapped with those of the priest." 73

Ben Sira regarded his status as superior to that of day labourers, farmers and ordinary craftsmen (cf. Sir 38:24-34). His attitude towards the "non-scribal

65 The book's name is "Sirach," while the author is named "Ben Sira."

66 Cf. Charles Buttigieg, "The Book of Ben Sira: Connecting the Jews All Over the Greek World," ScrB 44/1 (2014). Pancratius C. Beentjes says that the publication date can be "established quite accurately" between 200 and 180 BCE. See "Canon and Scripture in the Book of Ben Sira (Jesus Sirach /Ecclesiasticus)," chapter 13 in Pancratius C. Beentjes, Happy the One who Mediates on Wisdom (Sir. 14,20). Collected Essays on the Book of Ben Sira", [Peeters: Leuven, 2006],169).

67 Cf. Buttigieg, "Ben Sira," 3.

68 Cf. John J. Pilch, "The Wisdom of Ben Sira in MENA Cultural Context: A Cultural Topical Index," HTS 72 (2016), article \#3212, page 1, doi: 10.4102/hts.v72i4.3212.

69 Buttigieg, "Ben Sira," 2. In 198 BCE Jerusalem came under the rule of the Seleucids. Cf. also Buttigieg, "Ben Sira," 3.

70 Victor Moria Asensio, "Poverty and Wealth: Ben Sira's View of Possessions," in Der Einzelne und seine Gemeinschaft bei Ben Sira. Beihefte zur Zeitschrift für die alttestamentliche Wissenschaft, ed. Renate Egger-Wenzel \& Ingrid Krammer (Berlin: Walter de Gruyter, 1998), 151-178.

71 Cf. Samuel L. Adams, "Poverty and Otherness in Second Temple Instructions," in The "Other" in Second Temple Judaism: Essays in Honor of John J. Collins, ed. Daniel C. Harlow, et al., (Grand Rapids: William B Eerdmans, 2011), 189-202; cf. also Benjamin G. Wright, III, and Claudia V. Camp, "Who Has Been Tested by Gold and Found Perfect? Ben Sira's Discourse of Riches and Poverty," Henoch 23/2-3 (2001): 167.

72 Phil J. Botha, "The Ideology of Shame in the Wisdom of Ben Sira: Ecclesiasticus 41:14-42," OTE 9 (1996): 358.

73 Wright and Camp, "Who Has Been Tested?" 167. 
classes"74 was patronising. Ben Sira's message to those below him on the social ladder was "mixed." 75 On the other hand, the retainer class was employed by the rich. Ben Sira and his fellow sages relied upon them for a livelihood. Ben Sira therefore had to perform a "delicate balancing act." " The "betwixt-and betweenness" 77 of his social position meant he could not criticise the rich too bluntly, but could not neglect to voice the rights of the poor. $\mathrm{He}$ had to steer between the relationships of rich and poor. Although he cannot provide a final solution for the differences between the poor and the rich (Sir 13:1-23), he aims at showing a way for some relationship. ${ }^{78} \mathrm{He}$ had to warn the rich and powerful against exploiting the poor, but simultaneously promoted almsgiving to the poor and helping one in need. This made him a mediator between the rich and the ordinary Jew. According to Wright \& Camp this ambivalence made him sensitive to his social status and the "theologically elevated view of his profession." work.

\section{Sirach and Poverty}

Ben Sira often talks about poverty and the unfortunate state of the poor. $\mathrm{He}$ refers to wealth and poverty in Sir 10:30-11:6,14; 11:10-11, 14, 23-28; 13:3, $21-14: 10 ; 25: 2 ; 26: 28-27: 3$; and $31: 1-11{ }^{80}$ The most frequent term used in Sirach for poor or poverty is $\pi \tau \omega \chi \chi \sigma^{\prime} s(21: 5 ; 26: 4 ; 29: 22 ; 31: 21){ }^{81}$ Other terms

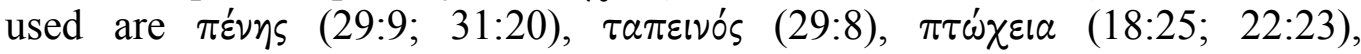
$\tau \alpha \pi \varepsilon^{\prime} v \omega \sigma 1 \zeta(2: 4.5)$ and $\varepsilon v \delta \varepsilon 1 \alpha(18: 25 ; 20: 21 ; 26: 28){ }^{82}$ The author of Sirach understands these concepts in terms of honour and shame. ${ }^{83} \mathrm{He}$ instructs "his audience to avoid corruption and care for the poor, and he repeatedly emphasises the importance of almsgiving (Sir 3:30; 7:10; 12:3; 17:22; 29:8, 12; $35: 4 ; 40: 17,24) .{ }^{"}{ }^{4} \mathrm{He}$ never neglects to urgently summon the hearer "zu

74 Samuel L. Adams, “Rethinking the Relationship between'4QInstruction' and 'Ben Sira," RevQ 24 (2010): 559.

75 Adams, "Rethinking," 559.

76 Adams, "Poverty and Otherness," 167.

77 Wright and Camp, "Who Has Been Tested?" 163.

78 Cf. Asensio, "Poverty and Wealth," 167-168.

79 Wright and Camp, "Who Has Been Tested?" 163.

80 The topical index of issues in Ben Sira in Pilch, "Wisdom of Ben Sira," 3, modifies that of Patrick W. Skehan and Alexander A. Di Lella, The Wisdom of Ben Sira, AB 39 (New York: Doubleday, 1987), 4-6, adding cultural anthropological Middle Eastern North African (MENA) values such as honour and shame and collectivism to it. Pilch "Wisdom of Ben Sira," 9, proposes to read books like Proverbs and Ben Sira "with the aid of a cultural topical index."

81 Cf. Asensio, "Poverty and Wealth," 154.

82 Cf. Asensio, "Poverty and Wealth," 156.

83 Cf. Pilch, "Wisdom of Ben Sira," 3.

84 Adams, "Rethinking," 559. 
Venter, “Different Perspectives on Poverty,” OTE 30/2 (2017): 478-502

Hilfsleitungen für die Bedürftigen" (to assistance of the needy) ${ }^{85}$ (cf. Sir 29:8f $\mathrm{f}^{86}$ ). An urgent appeal to charity and support of the poor is found in Sir $4: 1-10$.

According to Wright \& Camp "riches and poverty are not metaphorical concepts" 87 in the book of Sirach. His discourse on these concepts is "derived from the real-life circumstances of third- and second-century BCE Jerusalem." 88 When the book of Sirach talks of rich and poor "he talks almost exclusively in terms of people who do or do not have material wealth." 89 Sirach 4 warns not to cheat the poor of their living. ${ }^{90}$ In 17:22 it is stated that "almsgiving is like a signet ring with the Lord." Sirach's understanding of wealth and poverty can be summarised with 40:26 ("Riches are good, but the fear of the Lord is better than either," NRSV) and 13:24 ("Riches are good if they are free from sin," NRSV). Although wealth is "socially higher than poverty,"91 it is quite important for Ben Sira what the affluent person does with his wealth. ${ }^{92}$ Wealth can easily lead to injustice, violence and crime. Wealth should rather be used for providing surety, giving alms and upholding the cult. $^{93}$ In the short poem of Sir 29:8-13 almsgiving is proposed for the commandment's sake (cf. Deut 15:7-11). Sirach is realistic and never indicates that being poor is being pious. ${ }^{94}$

Sira does not view poverty as a "guilty, self-induced situation." 95 It is rather the "outcome of fate, idleness, unfavourable circumstances in life, and robbery by the rich people." 96 Sirach advises people in this position to remain faithful to God and never give up hope. ${ }^{97}$ Some time or another God will reward those who are faithful to him even if they are poor. The poor do have

85 Volkmar Premstaller, “'Nimm dich des Bedürftigen an!' (Sir 29,9); Weisheitliche Lehren zur Armut," ZKT 129/3-4 (2007): 488.

86 Verse 9: "Help the poor for the commandment's sake, and in their need do not send them away empty handed."

87 Wright and Camp, "Who Has Been Tested?" 153.

88 Wright and Camp, "Who Has Been Tested?" 172.

89 Wright and Camp, "Who Has Been Tested?" 153.

90 Cf. also Sir 34:24-27. Sirach 34:24 reads: "The bread of the needy is the life of the poor."

91 Asensio, "Poverty and Wealth," 157.

92 Cf. Wright and Camp, "Who Has Been Tested?" 156.

93 Cf. Asensio "Poverty and Wealth," 160.

94 Cf. Wright and Camp, "Who Has Been Tested?" 159.

95 Asensio, "Poverty and Wealth," 171.

96 Asensio, "Poverty and Wealth," 171.

97 Cf. Asensio, "Poverty and Wealth," 171. 
"some special place in God's eyes." ${ }^{98}$ Although God is impartial, He is just and does listen to the prayer of the oppressed.

\section{$3 \quad$ Sirach and Proverbs}

In certain respects, Sirach's view is congruent to that of Proverbs. Sirach definitely harks back to the Book of Proverbs. ${ }^{99}$ Both Proverbs and Sirach "take the form of a manual designed to guide young men and women in behavior." These handbooks teach learners how to instil the inherited values of the sages and to avoid stupid actions. Both may be "classed as scribal wisdom."101

Similar literary forms ${ }^{102}$ and themes are found in both. Both Sirach and Proverbs close with an acrostic poem in which they depict a personified wisdom (Prov 31:10-31; Sir 51:13-30). Numerical sayings are found in both (Prov 30:15b-16, 21-23; Sir 25:1-2; 26:5-6). With regard to poverty both Proverbs and Sirach recommend benevolence for those who are poor and in need. ${ }^{103}$ Ben Sira also links righteousness to giving alms to the poor. ${ }^{104}$ Sirach also comes to the conclusion that "poverty is a desolate, unenviable state." 105 Sirach also advises the reader to avoid corruption in financial affairs.

In Sir 4 the "Jahrhunderte älteren Teilen des Sprichwörtebuches" (centuries older sections of the proverbs collection) ${ }^{106}$ are reflected. Corley remarks that there is a "complexity and subtlety" 107 in Sirach's use of literature from Proverbs. Corley assumes that Ben Sira "had access to the Hebrew text of Proverbs." 108 According to Corley Sirach not only alludes to Proverbs, but rather uses key words with which he plays, applying them to a different context without using "extensive verbatim quotations." 109 Corley finds similarities between Proverbs and Sirach in three areas: theology, social ethics, and formal

98 Wright and Camp, "Who Has Been Tested?" 159.

99 Cf. Beentjes, "Canon and Scripture," 595.

100 Perdue, The Sword and the Stylus, 103.

101 Jeremy Corley, "An Intertextual Study of Proverbs and Ben Sira," in Intertextual Studies in Ben Sira and Tobit: Essays in Honor of Alexander A. Di Lella, O.F.M., ed. Jeremy Corley and Vincent Skemp, CBQMS 38 (Washington: The Catholic Biblical Association of America, 2005), 157.

${ }^{102}$ Cf. Buttigieg, "Ben Sira," 11, notes on the literary genre of Sira. Although similar in style as Proverbs, there are approximately hundred literary forms that "have clear parallels in pagan literature."

${ }^{103}$ Cf. Corley, "Intertextual Study," 179-180.

104 Cf. Corley, "Intertextual Study," 179. Cf. Prov 10:2; 11:14 with Sir 40:24.

${ }^{105}$ Adams, "Poverty and Otherness," 168.

106 Premstaller, "Weisheitliche Lehren," 488.

107 Corley, "Intertextual Study," 152.

${ }^{108}$ Corley, "Intertextual Study," 156. In whatever form it was available at the time of course.

109 Corley, "Intertextual Study," 157. 
structure. ${ }^{110} \mathrm{He}$ investigates these as: "theological similarities," "si11 "similarities in the area of social ethics," 112 and "similarities of structure and form." Numerical sayings occur in all three. While these subjects are dispersed in Proverbs, they are thematically ${ }^{114}$ organised in Sirach. ${ }^{115}$

Of concern, is Sirach's view as found in the section of social ethics. Sirach also links the expression of poverty to the language of honour and shame. While the topic of honour and shame is dealt with in different sections of Proverbs, Ben Sirach's ideas on this theme is found in several poems (Sir 4:20-22; 10:19-11:6; 201:21-26; 41:16-42:8; 42:9-14. ${ }^{116}$ Avoiding shame is "more prominent in Ben Sira"117 than in Proverbs. Sirach also refers to the expression "fear of the Lord" (Prov 1:7; 9:10). Buttigieg indicates fear of God as the book's "overall theme (Gesamtthema)."118 Asensio also sees this theologumenon as the "nuclear theme"119 in Sirach. In Sirach "fear" plays a larger role than merely conveying piety. ${ }^{120}$ Sirach "expands this so that to fear the Lord is also wisdom's fullness, garland, and $\operatorname{root}(\operatorname{Sir} 1: 14,16,18,20) . " 121$

However, there are also some differences between Proverbs and Sirach. Sirach "adapts much of the content in Proverbs." 122 Sirach lacks the comfort level of the Proverb sages, and "their confidence in the observable moral order of the world and their place in it." 123 Proverbs is also "much more wedded to a theologized logic of material retribution than is Ben Sira." ${ }^{124}$ In his probable

\footnotetext{
110 Cf. Corley, "Intertextual Study," 172.

111 Corley, "Intertextual Study," 158-167.

112 Corley, "Intertextual Study," 167-180.

113 Corley, "Intertextual Study," 180-182.

114 The issue of organisation is linked to the structure of the book of Sirach. Different scholars parsed Sira into different sections. Buttigieg, "Ben Sira," 13, refers to J. D. Harvey, who sees "a degree of order in the book."

${ }^{115}$ Cf. Jonathon Lookadoo, "Sirach, Book of, Critical Issues," In The Lexham Bible Dictionary. Edited by John D. Barry, David Bomar, Derek R. Brown, Rachel Klippenstein, Douglas Mangum, Carrie Sinclair-Wolcott, and Wendy Widder. Bellingham, WA: Lexham Press, 2016. Logos electronic edition.

116 Cf. Corley, "Intertextual Study," 167.

117 Corley, "Intertextual Study," 167.

118 Buttigieg, "Ben Sira," 14.

119 Asensio, "Poverty and Wealth," 173.

120 Cf. Wright and Camp, "Who Has Been Tested?" 162.

121 Lookadoo, "Sirach, Book of," electronic ed.

122 Lookadoo, "Sirach, Book of," electronic ed.

123 Wright and Camp, "Who Has Been Tested?" 161-162.

124 Wright and Camp, "Who Has Been Tested?" 162.
} 
third century BCE situation Sirach "is unable to maintain the consequential relationship of righteousness and wealth found in Proverbs." 125

\section{Other Sources for Sirach}

According to Adams, Ben Sira followed "longstanding modes of discourse."126 Buttigieg also states that Ben Sira "also derived material from gentile sources." 127 According to Buttigieg "there are perhaps about a hundred texts in Sirach that have clear parallels in Greek literature."128 Egyptian influences can also be detected in Sirach. Sirach reflects "Homer in 14:18 and the Greek poet Theognis elsewhere." ${ }^{29}$ Another example is the sayings of the "Demotic Egyptian "Instruction" of the sage Phibis (or Phebor) ... as preserved in Papyrus Insinger." ${ }^{130}$ Ben Sira incorporates the Torah in his work, ${ }^{131}$ but rejects mantic wisdom. ${ }^{132}$ Wright $^{133}$ identifies three sources for Sira: ${ }^{134}$ Torah, the oral tradition of the sages, and "observation of the natural world." According to Adams 135 "the bulk of the instruction stands in the tradition of Proverbs and other ancient Near Eastern texts." 136 The emphasis lies on the sharing and internalising of maxims. The Israelite literary tradition, therefore, is not the only source of Ben Sira. There are several sources. Corley refers to "other influences (Hebrew, Greek, and Egyptian) that caused Ben Sira to develop the

125 Wright and Camp, “Who Has Been Tested?" 173.

126 Adams, "Rethinking," 578.

127 Buttigieg, "Ben Sira," 4.

128 Buttigieg, "Ben Sira," 4

129 Buttigieg, "Ben Sira," 4

130 Buttigieg, "Ben Sira," 4. In this publication Buttigieg indicates the study of ancient Jewish quotations in Sira as a future field of research.

131 A well-known example is found in Sir 24:1-22 where Wisdom in the form of personified Torah is linked to the temple in Jerusalem.

132 Cf. Adams, "Rethinking," 578.

133 Benjamin G. Wright, III, "Biblical Interpretation in the Book of Ben Sira," in A Companion to Biblical Interpretation in Early Judaism, ed. Matthias Henze (Grand Rapids: William B. Eerdmans, 2012), 367.

134 The same sources are indicated in Benjamin G. Wright, III, "The Use and Interpretations of Biblical Tradition in Ben Sira's Praise of the Ancestors," in Studies in the Book of Ben Sira: Papers of the Third International Congress on the Deuterocanonical Book, Shome'on Centre, Papa, Hungary, 18-22 May, 2006, ed. Geza G. Xeravits and Joszef Zsengeller (Leiden: Brill, 2008). He states on p. 184 "the traditional scribal wisdom that Ben Sira learned and then taught undoubtedly has a significant oral component, a few places in his book suggest that at least what he calls "Torah" is not always somebody of oral teaching, but it actually involves some written/ textual preservation of the law of God."

135 Adams, "Rethinking," 578.

136 Cf. Wright, "Biblical Interpretation," 382. 
teaching that he found in Proverbs." ${ }^{\prime 37}$ With regard to Sir 24 Corley sees ${ }^{138}$ influence "beyond Proverbs 8 to encompass other books of the HB (and doubtless non-biblical material) ..."139 In Sir 36 and 39 prophetic elements are woven into Sirach's words. Ben Sira probably had "the biblical commandments in front of him" 140 encouraging care for the poor and the oppressed. In Sir 11:17 the sceptical wisdom of Qohelet is reflected "in the first half of the verse and Proverbs' theological optimism in the second half." ${ }^{141}$ While the theme of poverty initially was a "Randthema" (marginal theme) ${ }^{142}$ in the wisdom literature of Proverbs, Job and Qoheleth, it became increasingly important and is now found mainly in Sirach ("vor allem in Sir wesentlich häufiger vorkommen"). ${ }^{143}$ According to Corley Sir 3:30 develops Prov 16:6 "along the lines of Tobit 12:9 and the Septuagint of Daniel 4:27." ${ }^{144}$ He links atoning value to almsgiving. In line with Prov 26:3 he advises to treat stubborn slaves harshly. Slaves are not to be enclosed with those who are to be taken care for. ${ }^{145}$ This is in line with Papyrus Insinger 14:6-11 that advises to beat those who are inferior. ${ }^{146}$

\section{$5 \quad$ Sirach and the Eventual Biblical Canon}

Identifying the sources, the way they were transmitted and the authority they had for Ben Sira, is quite problematic. These issues are linked to "the difficult problem of the development of the biblical canon in the Second Temple period." 147 In the Prologue of the book Ben Sira, the son of Sira, refers to his grandfather "who had devoted himself especially to the reading of the Law and the Prophets and the other books of our ancestors, and had acquired considerable proficiency in them"148 Whether this "Law and Prophets" is

137 Corley, "Intertextual Study," 155.

138 In Sir 24:1-22 (see also Sir 1:4-20) the personified wisdom of Prov 8 is identical to the personified Torah (see Sir 24:23; 19:20). Wisdom is God's gift and is to be sought diligently by human beings (Sir 4:17-19; 6:23-31). Wisdom in the form of Torah is now linked to the temple in Jerusalem.

139 Corley, "Intertextual Study," 160.

140 Wright and Camp, "Who Has Been Tested?" 161.

141 Wright and Camp, "Who Has Been Tested?" 170.

142 Premstaller, "Weisheitliche Lehren," 481.

143 Premstaller, "Weisheitliche Lehren," 481.

144 Corley, "Intertextual Study," 179.

145 Cf. Corley, "Intertextual Studies," 179.

146 Cf. Corley, "Intertextual Studies," 180.

147 Buttigieg, "Ben Sira," 5-6, pays attention to another aspect of canonicity: the canonicity of Sira itself. He distinguishes between books being accepted as canonical and those only approved for public reading. Sira may have fallen in this last category. Although never quoted in the NT, Sira is quoted in works like the Didache, Barnabas, Clement of Alexandria, and Origen.

148 Prologue v. 7-11 Sirach, NRSV. 
identical to the final canonical form ${ }^{149}$ of the Torah (Law) and Nebiim (Prophets) as we know it today, or just a collection still in process, is not clear. Wright therefore avoids the question whether the sources Ben Sira used can be called canonical or just scripture. According to Wright Ben Sira was rather "scripture conscious," 150 than "canonical conscious." 151 Ben Sira stands in line with traditional wisdom teachers like those who produced Proverbs and Job, but "now looks to the Israelite literary heritage for inquiring into wisdom." ${ }^{152}$ Ben Sira is concerned with traditions of all kinds (the wisdom of the ancients, prophecies, the sayings of the famous, subtle and obscure parables, proverbs with hidden meanings, cf. Sir 39:1-3). According to Wright, when Ben Sira used various sources, he "manipulates, transforms, and otherwise shapes them to fit his own agenda." 153 By interpreting ${ }^{154}$ these sources he created a "figured world" 155 and depicted his view of the world and the role his students are to play in it as a pedagogical strategy. Ben Sira clearly tried to co-opt these sources in creating this "world."156

\section{Summary of Sirach}

Sirach was written during the second century BCE and reflects the circumstances of that time. The book "marks a decisive transition in wisdom literature by identifying Wisdom with the Torah $(19: 20 ; 24: 23) . " 157$ As member of the retainer class Ben Sira stood between the ordinary Jews and the elite, being a mediator between both sides. His references to the poor is to be understood literally. ${ }^{158} \mathrm{He}$ urges his learners to look after the poor. In some regard his work overlaps with that of Proverbs using similar linguistic techniques.

149 In the encomium of Sir 44:1-50:24 it refers to people like Joshua, the Judges, Samuel, the Kings of Israel, Isaiah, Jeremiah, Ezekiel and the Twelve prophets. The book does not refer to Ruth, Song of Songs, Esther or Daniel. This is an indication that the collections of Law and Prophets could have been in an advanced state of formalization when the son of Sira translated the work, while the section of the Writings was still in flux at the end of the second century BCE.

150 Wright, "Biblical Interpretation," 385.

151 Wright, "Biblical Interpretation," 385.

152 Wright, "Biblical Interpretation," 366.

153 Wright, "Biblical Interpretation," 382.

154 Cf. Wright, "Biblical Interpretation," 367-370.

155 Wright, "Biblical Interpretation," 367.

156 Wright, "Categories," 101.

157 Buttigieg, "Ben Sira," 7.

158 Asensio, "Poverty and Wealth," 175, sees wisdom as referring to both spiritual as well as "humanistic" goods. Keeping in mind "the ambiguity involved in the human and social reality" (Asensio, "Poverty and Wealth," 176) the God-fearing poor person can be wise while the rich person can be a fool. Fellowship with wisdom for both the poor and the wealthy is their "supreme wealth" (Asensio, "Poverty and Wealth," 177). Literal poverty does not prevent someone to be spiritually wealthy. 
Corley ${ }^{159}$ identifies different areas of resemblance between Proverbs and Sirach. Generally, the concept of honour and shame plays a larger role in Sirach than in Proverbs. Sirach's presentation of these topics is also more systematic than that of the variegated collection of Proverbs. The two forms of scribal wisdom also differ from each other. Ben Sira not only re-contextualises the saying of Proverbs in a second century BCE framework, he also sets his teaching in a much broader intertextual structure. He complements his ideas with the cognitive content found in the biblical Law and Prophets, as well as those in other contemporary Near Ancient texts. Quoting, alluding and referring to them, he creates a "figured world" 160 around the wisdom theme. Poverty functions within this "intertextual connections" 161 in Sirach. With regard to the phenomenon of poverty the wisdom oriented literature in Sirach evolved into a more literary application of the material found in Proverbs and elsewhere.

\section{4QINSTRUCTION}

\section{The Provenance of the So-Called 4QInstruction}

It is quite difficult to pinpoint the provenance of 4 QInstruction. Searching for a background "one frequent move is to compare 4 QInstruction with Ben Sira and to situate it within the same timeframe, in the early part of the second century B.C.E." 162 Some argue that they overlap and that there was a dialogue between the two sapiential works ${ }^{163}$ localising both in the pre-Maccabean era. ${ }^{164}$ Adams concedes that "there are enough parallels to demonstrate certain mutual interests and roughly similar periods of composition." 165 They share a "pedagogical ethos"166 and a pedagogical setting. Both try to infuse a love for learning in their students. ${ }^{167}$ In subject matter, much of 4 QInstruction "resonates"168 with the wisdom tradition also found in Proverbs. A common application of the Genesis creation stories is found in both. The commonalities between them can indeed help us to "identify important developments in the

\footnotetext{
159 Corley, "Intertextual Study."

160 Wright, "Biblical Interpretation," 367.

161 Kynes, "Modern Scholarly," 32.

162 Adams, "Rethinking," 556.

163 For instance, Jean-Sébastien Rey, 4QInstruction: sagesse et eschatology, STDJ 81 (Leiden: Brill, 2009).

164 Cf. Adams, "Rethinking," 557.

165 Adams, "Rethinking," 558.

166 Mark D. Matthews, "Riches, Poverty, and the Faithful: Perspectives on Wealth in the Second Temple Period and the Apocalypse of John," (PhD diss., Durham University, 2010), 94.

167 Cf. Matthew J. Goff, 4Qinstruction, WLAW 2 (Atlanta: Society of Biblical Literature, 2013), 13.

168 Goff, 4QInstruction, 13.
} 
Second Temple wisdom tradition." 169

\section{A New Direction for Wisdom Literature}

4QInstruction has material that is alien to the traditional biblical wisdom found in Proverbs. No specific context is provided in the text of 4QInstruction. When it refers to a social context, it is so general that it can fit any context. ${ }^{170}$ Both have "disparate viewpoints, generic conventions, and audiences." 171 They differ on issues like "the acquisition of knowledge, eschatology, and the acceptability of speculative wisdom." 172 Adams would rather choose for a later date for $4 \mathrm{QInstruction.} \mathrm{There} \mathrm{was} \mathrm{a} \mathrm{diversity} \mathrm{of} \mathrm{wisdom} \mathrm{opinions} \mathrm{during} \mathrm{the} \mathrm{period} \mathrm{of}$ the Second Temple (516 BCE-70 CE) and texts do not necessarily have to come from the same time. As far as vocabulary is concerned, 4QInstruction has anyway more in common with other Dead Sea Scrolls than with Sira and Biblical literature. ${ }^{173}$

The most obvious difference pertains to apocalyptic literature. The traditional assumptions of wisdom literature are now recontextualised in 4 QInstruction "in light of the heavenly and temporal realities in a manner familiar to us from apocalyptic literature." ${ }^{\prime 14}$ Sirach and 4QInstruction "diverge radically on eschatology and divine retribution." 175 In 4QInstruction a fortunate afterlife is promised to the learner. Sira "vehemently dismisses this possibility." ${ }^{" 176}$ Sirach is totally disinterested in any eschatology and rejects it. It "does not incorporate apocalyptic eschatology in his traditional advice." 177 While 4QInstruction has "a developed framework for eschatological judgement," ${ }^{178}$ Sirach does not accommodate an afterlife in its teachings. 4 QInstruction "combines the eudemonistic and educational ethos of traditional wisdom with an apocalyptic worldview." 179 4QInstruction also differs from most other wisdom texts because it puts the standard wisdom advice in a

169 Adams, "Rethinking," 558.

170 Cf. Wright, "Categories," 105.

171 Adams, "Rethinking," 558.

172 Adams, "Rethinking," 558.

173 Cf. Sneed, "Introduction," 57-58; Adams, "Rethinking," 570.

174 John Kampen, Wisdom Literature, "The First Forty Years of Research," (Grand Rapids: Eerdmans, 2011), Kindle edition ch. 1.

175 Adams, "Rethinking," 580.

176 Adams, "Rethinking," 580.

177 Adams, "Rethinking," 581.

178 Adams, "Rethinking," 583.

179 Matthew J. Goff, "Wisdom, Apocalypticism, and the Pedagogical Ethos of 4Qinstruction," (paper presented at the Annual Meeting of the Society of Biblical Literature, Toronto, 11 November 2002), 1, https://www.sbl-site.org/assets /pdfs/Goff.pdf. 
cosmological and eschatological context. ${ }^{180}$

In Sirach the priestly authorities are needed to pursue a scribal profession. ${ }^{181}$ Those in 4QInstruction do not deal with priestly matters whatsoever. 4QInstruction rather deals with "individuals more on the margin of society who would not have to come into regular contact with such persons." "182 The addressees are also totally different. Ben Sira's students belong to the retainer class. They are trained to become officials in the community in the capacity of judges, councilors and scholars. ${ }^{183}$ The addressees in 4QInstruction are not destined to become leaders in public. Their socio-economic background is totally different, even including women. The addressees of 4QInstruction are rather those who have to struggle with the problem of poverty. Reference to wealth is never found in 4QInstruction. Unlike Sirach that deals with wealth, this work concentrates much more on poverty. ${ }^{184}$ The learners in 4QInstruction are advised how to deal with issues like debt, standing surety for another and how to deal with deprivation. While Sirach emphasises the importance to his students of caring for the poor, the addressees in 4QInstruction are the poor themselves. ${ }^{185}$ While Sirach has the larger society in mind, 4QInstruction addresses those on the margin who are poor. ${ }^{186}$

\section{The Poverty of the Maven}

One of the "consistent emphases of 4QInstruction"187 is on the poverty of the learner. It seems to be "something of a preoccupation of 4Qinstruction." 188 The "maven" (addressee, learner ${ }^{189}$ ) is repeatedly ${ }^{190}$ reminded, "You are poor." Scholars interpret "poor" in different ways. It usually denotes the low status of the learner. The question for Adams ${ }^{191}$ is whether one should "take the frequent poverty language in the text literally or figuratively." ${ }^{192}$ Wright sees no other

\footnotetext{
180 Cf. Wright, "Categories," 106.

181 Cf. Adams, "Rethinking," 564.

182 Adams, "Rethinking," 565.

183 Cf. Wright, "Categories," 111.

184 Cf. Wright, "Categories," 107.

${ }^{185}$ Cf. Wright, "Categories," 110.

186 Cf. Adams, "Rethinking," 563.

187 Wright, "Categories," 107.

188 Wright, "Categories," 107.

189 Joshua Ezra Burns, "Practical Wisdom in 4QInstruction," DSD 11/1 (2004): 12, online: http://www.jstor.org/stable/4193305?seq=1\#page scan tab contents, footnote 1 , renders this often used term in 4QInstruction as "one who understands." He is a learner, "a perceptive individual."

190 Twenty five times. Cf. 4Q415 6 2; 4Q416 2 II 20; 4Q416 2 III 2,8,12,19; 4Q418 177 58; 1043 II 2-9; 4Q418 81 15,19; 4Q423 3 2; 4Q423 55.

191 Adams, "Rethinking," 556.

192 Adams, "Rethinking," 556.
} 
way than to read this term as "reflections of social realities." 193 Adams also sees this term as pointing at "a situation of real poverty for many recipients of the advice." 194 Although this term is unique in Second Temple instructions, the "acute circumstances for the audience of 4QInstruction makes any financial advice even more important." 195 Wright even asks if "poverty constitutes an ideal value for 4Qinstruction."196 Does "the sage of 4QInstruction prefers a way of life characterized by poverty"? ${ }^{197}$

The idea of poverty has both a literal as well as a metaphorical meaning in 4QInstruction. The addressees experienced real poverty in several forms. However, what 4QInstruction does, is to present a theological construct to help the addressees to cope with their circumstances. Hoppe is of opinion that this term in 4QInstruction deals with historical, political and economic matters, but also serves as "metaphor for another reality." 198 It is simultaneously a metaphor for a theological construct. This is presented in 4QInstruction in the form of a Motivkonstellation (construct of motifs) of four interlinked terms: poverty, elected status, inheritance and raz nihyeh (the secret to be). ${ }^{199}$

The concept of poverty in 4QInstruction operates within a four-corner heuristic model. This model can mainly be found in 4Q416 2 III lines 5-19. ${ }^{200}$ The Hebrew term "raz nihyeh" (the mystery that is to be) ${ }^{201}$ is the most often

193 Wright, "Categories," 113.

194 Adams, "Rethinking," 561.

195 Adams, "Rethinking," 561, note 18.

196 Wright, "Categories," 113.

197 Wright, "Categories," 113.

198 Leslie J. Hoppe, There Shall Be No Poor Among You: Poverty in the Bible, (Nashville: Abingdon, 2004), 7.

199 Torleif Elgvin, “An Analysis of 4Qinstruction," (PhD diss., Hebrew University of Jerusalem, 1997), 58-159, identified five main themes in 4QInstruction: revelation eschatology, remnant community, creation-man-providence, and various areas of human life. Kampen, Wisdom, ch. 1, identifies some "Key Terms" in 4QInstruction: Mystery of existence, inner desire, man of discernment, wisdom, poverty, intention, walk.

200 The translation and parsing of Goff, 4Qinstruction, is followed here.

201 It can be translated as "the mystery that is to come" (John J. Collins, Jewish Wisdom in the Hellenistic Age [Louisville: Westminster John Knox, 1997], 121), "the mystery that is to be" (John J. Collins, "Wisdom Reconsidered, in Light of the Scrolls," DSD 4/3 [1997]: 272, doi: 10.1163/156851797X00137), "mystery of existence" or "the mystery of that which is coming into being" (cf. Michael A. Knibb, "The Book of Enoch in the Light of the Qumran Wisdom Literature," in Wisdom and Apocalypticism in the Dead Sea Scrolls and in Biblical Tradition, ed. F. García Martínez [Leuven: Leuven University Press, 2003], 200). Goff, 4QInstruction, constantly translates the term as "the mystery that is to be" Cf. also Goff, 4QInstruction, 33-34, for the different possibilities of translating this phrase. 
used term in $4 Q$ Instruction. It is found thirty-five times in the extant manuscripts of 4QInstruction. This concept forms the "core of 4QInstruction" 202 and is "the main tool""203 for obtaining wisdom. The mebin (learner) is urged to constantly study this mystery. This mystery teaches him the way God has ordered the world. The learner is assured that God gave him glory and part in his plans. He will inherit eternal life. Although being poor at the moment, this rich inheritance is promised to him in the life hereafter.

The mebin (learner) is assured that he also has an elect status. God has set him with the nobles (i.e. the angels). He shares the final allotment of the heavenly beings. Although suffering some form of poverty at the moment, he will share in eternal glory. He can view himself as "chosen and therefore privy to the deeper understanding of things," 204 as revealed in this raz nihyeh he studies.

The learner inherited something that "is superior to monetary wealth."205 Being elected, knowing God's secrets, assured of his inheritance, he is now able to maintain his "dignity and sense of well-worth, while in a difficult situation of indebtedness." ${ }^{206}$ He may be literally poor, but can live in a dignified way as member of God's plans for the world.

\section{Summary of 4QInstruction}

It is not possible to identify the exact provenance of 4QInstruction. It recalls older teachings of wisdom and shares a "pedagogical ethos"207 with Sirach. However, it differs radically with Sirach because of its apocalyptic worldview. While Sirach addresses future scribes of the retainer class, 4QInstruction communicates with those in the margin. The mebin (learner) is reminded again and again that he is poor. Sirach's pupils are to take care of those in destitution, the learners in 4QInstruction are literally the poor themselves. But the concept of poor has an additional metaphorical and ideological meaning in 4QInstruction. The concept of poverty is presented in a Motivkonstellation (constellation of motifs), a theological construct which proclaims that the poor are God's elected, although being poor at the moment. They have an eternal inheritance with the angels and already enjoy heavenly status, being part of God's raz

202 Matthew J. Goff, Discerning Wisdom: The Sapiential Literature of the Dead Sea Scrolls, VTSup 116 (Leiden: Koninklijke Brill, 2007), 13.

203 Goff, Discerning Wisdom, 10.

204 Sean Freyne, "Apocalypticism as the Rejected Other: Wisdom and Apocalypticism in Early Judaism and Early Christianity," in The "Other" in Second Temple Judaism: Essays in Honor of John J. Collins, ed. Daniel C. Harlow, et al. (Grand Rapids: Wm. B. Eerdmans Publishing, 2011), 249.

205 Goff, 4Qinstruction, 99.

206 Goff, 4QInstruction, 99.

207 Matthews, "Riches," 94. 
nihyeh (the secret to be) design.

\section{E SUMMARY}

Proverbs, Sirach and 4QInstruction have a "family resemblance"208 internally as well as externally. They present a dynamic continuity as well as a discontinuity in wisdom thinking. Each gave its own nuances to the concept of poverty. As a variegated collection of sayings Proverbs shows an ambivalent attitude towards the poor. In a constellation of different sapiential perspectives the elite warn the learner to look after the poor. The "poor" mostly has a literal sense, but also in some cases a figurative meaning. Ben Sira later on took up this term literally, while 4QInstruction developed it into a theological scheme.

Ben Sira contextualised the ideas in Proverbs in a second century BCE social and literal framework. Standing in a middle position between the common people and the elite, Ben Sira urged his learners to take care for the poor. Resemblance exists in different areas between Proverbs and Sirach. However, Sirach sets the material acquired from Proverbs and other literature from the ANE in the setting of a sapiential world of its own making.

4QInstruction forms part of the Dead Sea scrolls. It is not really possible at this stage of research to identify its real provenance. It shares the didactic ethics of Proverbs and Sirach, but differs radically from them with its apocalyptic worldview. 4QInstruction promises the really poor a heavenly inheritance. In a Motivkonstellation (constellation of motifs) it presents a theological construct of four interrelated terms (poor, elected, inheritance, and the secretto-be). 4Qinstruction therefore develops an additional metaphorical and ideological meaning of "poverty."

Poverty becomes the distinguishing mark here of the mebin assuring him or her of an eternal inheritance, privileged status and glory.

\section{BIBLIOGRAPHY}

Adams, Samuel L. Wisdom in Transition: Act and Consequence in Second Temple Instructions. JSJSup. Leiden: Brill, 2008.

. "Rethinking the Relationship between '4QInstruction' and 'Ben Sira."' $\operatorname{RevQ} 24 / 4$ (2010): 555-583.

. "Poverty and Otherness in Second Temple Instructions." Pages 189-202 in The "Other" in Second Temple Judaism: Essays in Honor of John J. Collins. Edited by Daniel C. Harlow, Karina Martin Hogan, Matthew Goff, and Joel S. Kaminsky. Grand Rapids: William B Eerdmans, 2011.

Asensio, Victor Moria, "Poverty and Wealth: Ben Sira's View of Possessions." Pages 151-178 in Der Einzelne und seine Gemeinschaft bei Ben Sira. Beihefte zur

208 Sneed, "Elusive Attempt," 62. 
500 Venter, "Different Perspectives on Poverty," OTE 30/2 (2017): 478-502

Zeitschrift für die alttestamentliche Wissenschaft. Edited by Renate Egger-

Wenzel \& Ingrid Krammer. Berlin: Walter de Gruyter, 1998.

Beentjes, Pancratius C., "Canon and Scripture in the Book of Ben Sira (Jesus Sirach

/Ecclesiasticus)." Pages 169-187 in "Happy the One who Mediates on Wisdom

(Sir. 14,20). Collected Essays on the Book of Ben Sira." Edited by Pancratius C.

Beentjes, Peeters: Leuven, 2006.

Botha, Phil J. "The Ideology of Shame in the Wisdom of Ben Sira: Ecclesiasticus

41:14-42:8." OTE 9/3 (1996): 353-371.

Burns, Joshua Ezra. "Practical Wisdom in 4Qinstruction." DSD 11/1 (2004): 12-42.

Online: http://www.jstor.org/stable/4193305?seq=1\#page_scan tab_contents.

Buttigieg, Charles. "The Book of Ben Sira: Connecting the Jews All Over the Greek

World." ScrB 44/1 (2014): 2-21.

Clifford, Richard J. "Proverbs, Book of." Pages 655-660 in vol. 4 of The New

Interpreter's Dictionary of the Bible. Edited by Katherine Doob Sakenfeld.

Nashville: Abingdon Press, 2009.

Collins, John J. Jewish Wisdom in the Hellenistic Age. Louisville: Westminster John

Knox, 1997.

"Wisdom Reconsidered, in Light of the Scrolls." DSD 4/3 (1997): 265-281.

Doi: 10.1163/156851797X00137.

Corley, Jeremy. "An Intertextual Study of Proverbs and Ben Sira." Pages 155-182 in

Intertextual Studies in Ben Sira and Tobit: Essays in Honor of Alexander A. Di

Lella, O.F.M. Edited by Jeremy Corley and Vincent Skemp. CBQMS 38.

Washington: The Catholic Biblical Association of America, 2005.

Elgvin, Torleif. “An Analysis of 4QInstruction.” PhD diss., Jerusalem: Hebrew

University of Jerusalem, 1997.

Fox, Michael V. "The Social Location of the Book of Proverbs." Pages 227-239 in

Texts, Temples, and Traditions: A Tribute to Menahem Haran. Winona Lake,

IN: Eisenbrauns, 1996.

Freyne, Sean. "Apocalypticism as the Rejected Other: Wisdom and Apocalypticism in

Early Judaism and Early Christianity." Pages 247-261 in The "Other" in Second

Temple Judaism: Essays in Honor of John J. Collins. Edited by Daniel C.

Harlow, Karina Martin Hogan, Matthew Goff, and Joel S. Kaminsky. Grand

Rapids: William B. Eerdmans, 2011.

Goff, Matthew J. "Wisdom, Apocalypticism, and the Pedagogical Ethos of

4Qinstruction." Paper presented at the Annual Meeting of the Society of

Biblical Literature, Toronto, November 11, 2002. https://www.sbl-site.org

/assets/pdfs/Goff.pdf.

. Discerning Wisdom: The Sapiential Literature of the Dead Sea Scrolls.

VTSup 116. Leiden: Koninklijke Brill, 2007.

. 4Qinstruction. WLAW 2. Atlanta: Society of Biblical Literature, 2013.

Hoppe, Leslie J. There Shall Be No Poor Among You: Poverty in the Bible. Nashville: Abingdon, 2004.

Kampen, John. Wisdom Literature. Grand Rapids: Eerdmans, 2011. Kindle edition.

Knibb, Michael A. "The Book of Enoch in the Light of the Qumran Wisdom

Literature." Pages 193-210 in Wisdom and Apocalypticism in the Dead Sea

Scrolls and in Biblical Tradition. Edited by F. García Martínez. Leuven: Leuven

University Press, 2003. 
Venter, "Different Perspectives on Poverty," OTE 30/2 (2017): 478-502

Koch, Klaus. “Gibt es ein Vergeltungsdogma im Alten Testament?” ZTK 52/1 (1951): $1-42$.

Kynes, Will. "The Modern Scholarly Wisdom Tradition and the Threat of PanSapientialism: A Case Report." Pages 11-38 in Was there a Wisdom Tradition? New Prospects in Israelite Wisdom Studies. Edited by Mark R. Sneed. Atlanta: SBL Press, 2015.

Loader, James Alfred. "Metaphorical and Literal Readings of Aphorisms in the Book of Proverbs." HTS 62/4 (2015): 1177-1199.

Lookadoo, Jonathon. "Sirach, Book of, Critical Issues." In The Lexham Bible Dictionary. Edited by John D. Barry, David Bomar, Derek R. Brown, Rachel Klippenstein, Douglas Mangum, Carrie Sinclair-Wolcott, and Wendy Widder. Bellingham, WA: Lexham Press, 2016. Logos electronic edition.

Matthews, Mark D. Riches, Poverty, and the Faithful: Perspectives on Wealth in the Second Temple Period and the Apocalypse of John. PhD diss., Durham University, 2010.

Perdue, Leo G. Wisdom Literature: A Theological History. Louisville: Westminster Kohn Knox Press, 2007. . The Sword and the Stylus: An Introduction to Wisdom in the Age of Empires. Grand Rapids: William B. Eerdmans, 2008.

Pilch, John J. "The Wisdom of Ben Sira in MENA Cultural Context: A Cultural Topical Index.” HTS Teologiese Studies ‘ Theological Studies 72/4 (2016), \#3212. Doi: http:dx.doi.org/10.4102/ hts.v72 4.3212.

Pleins, J. David. "Poverty in the Social World of the Wise."JSOT 37 (1987): 61-78.

Premstaller, Volkmar. "'Nimm dich des Bedürftigen an!' (Sir 29,9); Weisheitliche Lehren zur Armut." ZKT 129/3-4 (2007): 480-493.

Rey, Jean-Sébastien. 4QInstruction: sagesse et eschatology. STDJ 81. Leiden: Brill, 2009.

Sandoval, Timothy. The Discourse of Wealth and Poverty in the Book of Proverbs. Leiden: Brill, 2006.

Schellenberg, Annette. "Don't Throw the Baby Out with the Bathwater: On the Distinctiveness of the Sapiential Understanding of the World." Pages 115-143 in Was There a Wisdom Tradition? New Prospects in Israelite Wisdom Studies. Atlanta: SBL Press, 2015.

Skehan, Patrick W. and Alexander A. Di Lella. The Wisdom of Ben Sira. AB 39. New York: Doubleday, 1987.

Sneed, Mark R., ed. Was There a Wisdom Tradition? New Prospects in Israelite Wisdom Studies. Atlanta: SBL Press, 2015. . "Introduction." Pages 1-10 in Was There a Wisdom Tradition? New Prospects in Israelite Wisdom Studies. Atlanta: SBL Press, 2015. . "Grasping After the Wind': The Elusive Attempt to Define and Delimit Wisdom." Pages 39-67 in Was There a Wisdom Tradition? New Prospects in Israelite Wisdom Studies. Atlanta: SBL Press, 2015.

Spangenberg, Izak J. J. (Sakkie). "'The Poor Will Always Be with You': Wealth and Poverty in a Wisdom Perspective." Pages 228-246 in Plutocrats and Paupers: Wealth and Poverty in the Old Testament. Edited by Hendrik L. Bosman, Ignatius G. P. Gous, and Izak J. J. (Sakkie) Spangenberg. Pretoria: JL van Schaik, 1991. 
502 Venter, "Different Perspectives on Poverty," OTE 30/2 (2017): 478-502

Wright III, Benjamin G. and Claudia V. Camp. "Who Has Been Tested by Gold and Found Perfect': Ben Sira's Discourse of Riches and Poverty." Henoch 23/2-3 (2001): 153-174.

Wright, Benjamin G., III, "The Categories of Rich and Poor in the Qumran Sapiential Literature." Pages 101-113 in Sapiential Perspective: Wisdom Literature in the Light of the Dead Sea Scrolls: Proceedings of the Sixth International Symposium of the Orion Center, 20-22 May 2001. Edited by John J. Collins, Gregory E. Sterling and Ruth Clements. Leiden: Brill, 2004.

. "The Use and Interpretations of Biblical Tradition in Ben Sira's Praise of the Ancestors." Pages 183- 207 in Studies in the Book of Ben Sira: Papers of the Third International Congress on the Deuterocanonical Book, Shome'on Centre, Papa, Hungary, 18-22 May, 2006. Edited by Geza G. Xeravits and Joszef Zsengeller. Leiden: Brill, 2008.

. "Biblical Interpretation in the Book of Ben Sira." Pages 363-388 in A Companion to Biblical Interpretation in Early Judaism. Grand Rapids: William B. Eerdmans, 2012.

Prof Pieter M Venter, Emeritus Professor, University of Pretoria. P.O. Box 12060, Garden Route Mall, George, Western Cape, South Africa, 6546. Email: pmventer686@gmail.com. 